\title{
Investigating Cultural Dimensions in EFL Textbook by Using Byram Checklist
}

\section{*Soni Ariawan ${ }^{1}$}

Universitas Islam Negeri Mataram¹,

English Language Education Study Program, Faculty of Education and Teacher Training

E-mail : soniariawan@uinmataram.ac.id

Corresponding Author*

DOI: https://doi.org/10.18326/rgt.v13i1.123-152

\section{Submission Track:}

Received: 25-03-2020

Final Revision: 23-05-2020

Available online: 01-06-2020

\begin{abstract}
The present study is a content analysis that aims to investigate cultural dimension in an English textbook prescribed for senior high school in Indonesia which is officially published by the Ministry of Education and Culture in 2017. The data include 11 conversations, 17 reading texts, and 83 visual elements that are analysed qualitatively by employing Byram's checklist. The findings show that stereotypes and national identity dominate the cultural dimensions with $28.05 \%$ and followed by social interaction and socialisation and life cycle with $15.9 \%$. The occurrence of national geography
\end{abstract}


is significant with $12.2 \%$. However, social identity and social group, belief and behaviour, national history and social and political institutions are prescribed with less than 10\%. The inclusion of various cultural dimensions has certain purposes. The inclusion of national identity, for instance, is pivotal for learners since the textbook is prescribed for senior high school students who are tremendously curious to determine their characters. This idea is aligned with the aim of the curriculum to facilitate the development of students with good character, good behaviour and strong nationality. It is concluded that the English textbook in Indonesia is on the way to its perfection in terms of proportionally represented cultural dimensions. However, the presence of various cultural aspects of the target culture and international target culture is also important to help students develop cultural competence and a certain level of respect as well as tolerance for others.

Keywords: Textbook, cultural dimensions, cultural competence, national identity

\section{INTRODUCTION}

Cultural content is pivotal in the selection of an appropriate EFL textbook and the nurturing of cultural awareness in the minds of EFL learners (Bahrami, 2015). English as an international language (EIL) implies that learning English does not only involve considering the common ground that enables speakers to communicate like native speakers, but it must also consider the use of varieties of English that represent uniqueness and support language rights in the context of international communication (Jenkins, 2006). Native and non-native discourse and non-native and non-native discourse have to be culturally considered since they have particular intercultural insights and knowledge that are relevant to achieving pedagogical goals successfully (Alptekin, 2002).

In the context of Indonesia, the central government produces textbooks and distributes them to schools. The newest curriculum, the 2013 curriculum, was launched with a package of textbooks for junior and senior high school in 
REGISTER JOURNAL

Vol. 13, No. 1, (2020), pp.123-152

p-ISSN: 1979-8903 ; e-ISSN : 2503-040X

Website: http://journalregister.iainsalatiga.ac.id/index.php/register/

the middle of 2013. The Ministry of Education and Culture (MoEC) aims to achieve the national goal of character-based education through the textbooks. Consequently, they should be designed with the text and the context of learning in mind. The first edition of the textbook for the 2013 curriculum is crucial for encouraging English teachers to prepare relevant activities to support a successful teaching and learning process. The textbook also accommodates the diversity of Indonesian culture and contextualises it in an English language learning environment.

Many studies have been undertaken to analyse authentic content and cultural content in the Indonesian textbook. They have focused on investigating students' and teachers' experiences dealing with the EFL textbook. However, there are only a few local studies relating to the EFL textbook that the Ministry of National Education and Culture publishes. The textbook for the 2013 curriculum has been revised three times since 2014, and the previous study only explored cultural content in the 2014 version of the EFL textbook, but no local study has been undertaken regarding the 2017 version of the EFL textbook for the 2013 curriculum. This study aims to analyse cultural content in the 2017 EFL textbook for grade 10 in Indonesia using Byram's (1989) checklist to investigate how the culture is represented in the textbook.

The textbook is seen as a cultural artefact (Gray, 2000) that plays pivotal functions. It can be considered to be an ambassador for language practice, grammar, vocabulary, activities, and culture. In other words, textbooks are the entry point through which a certain group in the community 
reveals its cultural content. It can transmit social ideologies and practices (Apple \& Beyer, 1983). The real issue has to do with global course books that the British promoted in which the content incorporated government-backed enterprises in an economic and ideological agenda (Phillipson, 1992). The hidden agenda incorporated in the textbooks drew the attention of Moroccan English teachers because they assumed that native cultural content would lead to the erosion of belief (Hyde, 1994). It was also an issue in Saudi Arabia and China, where EFL textbooks have no references to English-speaking cultures (Gray, 2000).

Crawford (1990) argues that dealing with the negative effects of textbooks may distort the content because they often present an idealised, white, and middle-class view of the world and avoid controversial issues instead of addressing the specific needs of learners. Another point is that textbooks are produced for the global market and individuals' financial benefit. As a result, students may not be interested in learning, and they may find it difficult to process the language and content introduced since they are unfamiliar with the context (Alptekin, 1993). Hutchinson and Torres (1994) note that not only students but also teachers who do not follow textbook content in its entirety. They mostly adapt, change, add and delete some points. These problems are claimed to be the consequence of textbooks that focus solely on systematic knowledge (properties of language) rather than also focusing on schematic knowledge (which refers to socially-acquired knowledge) (Alptekin, 1993).

Cortazzi and Jin (1999) propose different ways of incorporating appropriate cultural content in language textbooks: They involve the source culture, target culture, and international target culture. "Source culture" is 
REGISTER JOURNAL

Vol. 13, No. 1, (2020), pp.123-152

p-ISSN: 1979-8903 ; e-ISSN : 2503-040X

Website: http://journalregister.iainsalatiga.ac.id/index.php/register/

related the learners' culture, with which they are familiar, and "target culture" refers to English-speaking countries' cultures or inner-circle countries' cultures (for instance, the cultures of the United States, Canada, Australia, the United Kingdom, and New Zealand). International target cultures concern a variety of cultures from around the world. The focus of cultural representation in EFL textbooks should accommodate proportional amounts of the source culture, target culture, and international target culture. It depends to a large extent on the learning objectives. Target cultures should not dominate the cultural content in EFL textbooks; local cultural representations are crucial as well (Hermawan \& Noerkhasanah, 2012). Learners can gain cognitive power and positive contributions to their zones of proximal development (ZDP) as they learn familiar content (Cummins, 1994), and strong personal attachment among teachers and learners is beneficial to the learning process (Isik, 2008).

Furthermore, the process of learning local culture through EFL in the classroom makes students interact and negotiate and define their own identities. Learning the target language ensures that students not only acquire sufficient basic EFL skills, verbalize their local cultural knowledge, and receive information about a foreign culture (Prastiwi, 2013). It is suggested that local educators or teachers determine the linguistic information, cultural content, and teaching methodology and pedagogy that are appropriate for the local context (McKay, 2003) so that learners can use English to tell others about their own culture.

Researchers have conducted extensive local and international studies of cultural content in English textbooks. They employ various theoretical 
frameworks as analytical frameworks to generate data and use quantitative and qualitative methods to analyse and present the data.

To begin with, Candrawati, Nitiasih, and Seken's (2014) study deals with sociocultural representation in an EFL textbook. They investigate age, gender, social distance and status, politeness strategies, genres, registers, major dialects, and background knowledge of the target language group in an EFL etextbook entitled Developing English Competencies in Indonesia. Qualitative discourse content analysis is the research method and a coding process is developed to collect the data. To analyse the data, qualitative and quantitative approaches are employed: The frequency of occurrences of sociocultural elements is observed and the description of elements in their entirety is presented. The findings show that the textbook is male-oriented and predominantly involves 12-to-18-year-olds. The study also concludes that the authors seem aware of the sociocultural aspects of the EFL textbook but are not aware of how to present them proportionally. However, the cultural aspects that this study highlights tend to highlight gender and sociolinguistic studies rather than comprehensive aspects of culture within an EFL textbook.

Another study, by Faris (2014), examines the EFL textbook, Look ahead, which was designed for senior high school in Indonesia. The study aims to determine the types of cultures presented and how they are presented. The data is selected from the reading passages, while the illustrations are only analysed if necessary. The study employs Cortazzi and Jin's (1999) approach regarding the type of culture (source culture, target culture, and international target culture) and Adaskou, Britten, and Fahsi's (1990) discussion of four senses of culture (the aesthetic sense, sociological sense, semantic sense, and pragmatic sense). Qualitative content analysis is used to analyse the data by selecting the 
REGISTER JOURNAL

Vol. 13, No. 1, (2020), pp.123-152

p-ISSN: 1979-8903 ; e-ISSN : 2503-040X

Website: http://journalregister.iainsalatiga.ac.id/index.php/register/

unit of analysis, selecting content categories, and analysing the data. The research findings reveal that the target culture is predominant at $77.05 \%$ and is mostly represented in the form of aesthetic sense.

Rashidi and Meihami (2016) also employ Cortazzi and Jin's (1999) and Adaskou et al.'s (1990) theoretical frameworks to examine three different secondary school ELT textbooks selected from the inner (the United Kingdom), outer (India) and expanding (Iran) circle countries. The purpose of the study is to explore the cultural content and to identify the cultural elements disseminated in the textbooks. The dialogue and reading sections are analysed using the two frameworks and quantitatively assessed (counted). The findings show that ELT textbooks of the inner, outer, and expanding circle countries represent L2 and international cultural content differently. Furthermore, different countries try to present their L1 cultural content more than cultural content from other countries. The inner circle countries tend to present L1 and L2 cultures when they design ELT textbooks, while the outer and expanding circle countries tend to insert more international culture for intercultural content and understanding. However, the three types of countries highlight aesthetic cultural elements most dominantly in the ELT textbooks.

Another theoretical approach is employed in the study by Chao (2011) in Taiwan. It adopts the five dimensions of culture including product, practice, perspective, community, and person (Moran, 2001). The data is collected from 20 units of the student book entitled New American inside out. The focus of the analysis includes the main reading texts and listening scripts (receptive skills), the main speaking and writing practices (productive skills), and the 
main pictures (visual texts), and it employs a coding process and adopted theoretical frameworks to generate the data. The study finds that perspective is the main cultural dimension described in the textbook followed by product, person, and practice, while community is the lowest. A similar theoretical framework is evident in Fitriyah's study (2015) on cultural content in a junior high school textbook in Indonesia entitled When English rings a bell, published by the Ministry of National Education and Culture. She uses Patrick Moran's (2001) categories of culture so-called knowing about, knowing how, knowing why, and knowing oneself to analyse the selected reading passages. The findings of this study confirm that the textbook includes the local perspective and exhibits features related to the local culture or source culture. This is why the government approves the textbook (Fitriyah, 2015). The study is not an indepth analysis and does not further address the language used in the textbook to indicate a certain dimension of culture.

Other theoretical approaches that examine cultural content in EFL textbook are present in (Piaget, 1928) and (Lee, 2007). Rodriguez and Espinar (2015) investigate three EFL textbooks for adults in Spain, employing these conceptual models of cultural learning that encompass knowledge, behaviour, and attitudes. They also use Lee's idea about specific culture: big $\mathrm{C}$ culture and small c culture explore the more specific aspects of culture revealed in the textbooks. Big $\mathrm{C}$ culture encompasses ethnic groups, geography/history/politics/regional variations, arts/crafts, and other visible elements of culture, while small c culture includes individualism/collectivism, equality, fairness, competition, materialism, confrontation, level of formality, and other invisible elements of culture. The study reveals that big $\mathrm{C}$ cultures tend to be the most dominant in the three textbooks. Interestingly, the small $\mathrm{c}$ 
REGISTER JOURNAL

Vol. 13, No. 1, (2020), pp.123-152

p-ISSN: 1979-8903 ; e-ISSN : 2503-040X

Website: http://journalregister.iainsalatiga.ac.id/index.php/register/

cultural aspects occur more frequently in B1-level textbooks. However, the discussion does not explain the reason for this finding. The study only focuses on investigating aspects of culture without further exploring the types of culture, that is, source culture, target culture, international target culture, or neutral culture.

Dweik and Al-Sayyed (2015) use another approach to examine an EFL textbook in Saudi Arabia. They employ a 12-item cultural checklist comprising history and politics, ecology, leisure time, music and the arts, names, literature and science, family and male-female relationships, education, food and drinks, religion and religious rituals, economy, dress, and social behaviour. It examines the conversation, reading passages, and pictures in a students' textbook and workbook. The findings of this study indicate that Arabic culture is more dominant, followed by international culture and British culture. History and politics are the cultural elements most often represented in the textbook. The researchers suggest to include more religious aspects in the EFL textbook because, in the context of Saudi Arabia, religion brings tolerance and teaches an understanding of different cultural backgrounds, which facilitates intercultural understanding.

Arsland (2016) develops a question checklist and item frequency analysis to investigate cultural content in EFL textbooks used for third and fourth grade students in a state school in Turkey. He specifies that the study solely explores the elements of native culture, target culture, and international culture revealed in the listening scripts and does not explore images and reading passages. The question checklist and item frequency analysis focus on 
finding general information and detailed information to facilitate data acquisition. The study finds that cultural items are represented more often in the textbook for the third grade than in that for the fourth grade, and the international cultural elements have the highest frequency in the textbooks. The researchers recommend that the textbook developer insert native culture as well as source culture in the content of EFL textbooks since they are fruitful for students' reflection about the values, beliefs, and traditions of other cultures and their own culture.

Cho and Park (2016) introduce another approach to analyse multicultural content in EFL textbooks in Korea. They investigate 52 textbooks for elementary and secondary students from the third to the ninth grade. A multicultural content analysis frame (MCAF) that includes identity, diversity and pluralism, and social justice and a multicultural description analysis frame (MDAF) that encompasses the balance of material distribution, accuracy and scope of information, distortion and stereotypes, a balance in perspectives, and Korean ethnic-centeredness. The study finds that minority groups are less represented in the textbooks, and this impacts the tension between ethnic nationalism and the multicultural perspective in Korean textbooks. A future study is suggested to find out what the accommodation strategies are for a multicultural country like Korea, whether they entail moving forward from nationalism to multiculturalism or maintaining nationalism and excluding multiculturalism even further to create a new model of multiculturalism within nationalism.

Aliakbari and Jamalvandi (2012) conduct an analysis of five high school textbooks in China that employs Ramirez and Hall's (1990) insights about cultural dimensions (social, personal, religion, arts, and the humanities). They 
REGISTER JOURNAL

Vol. 13, No. 1, (2020), pp.123-152

p-ISSN: 1979-8903 ; e-ISSN : 2503-040X

Website: http://journalregister.iainsalatiga.ac.id/index.php/register/

also highlight cultural categories that include Chinese, English-speaking countries', non-English-speaking Western countries', Eastern countries', and cross-national culture. The data is derived from the analysis of written and visual texts quantitatively by counting the frequency of occurrences through a coding process. The findings reveal that the most often represented cultural elements are religion, arts, and the humanities, while personal themes are the least described in the textbook. Furthermore, in terms of culture categories, the most frequently occurring cultural materials in both the written and visual modes are attributed to English-speaking countries (40\%), while the cultural materials associated with China constitute only $35 \%$, and those related to Eastern countries are the least highlighted. It is recommended that ELT textbooks in China be revised, and it is pivotal for material developers to present equal numbers of cultural dimensions as well as cultural categories.

The same theoretical approach is used to investigate instructional materials of the Iran Language Institute at the advanced level. Rashidi (2010) examines the vocabulary and reading section to gain the data and analyses them using Ramirez and Hall's (1990) categorizations. The findings reveal that more than $90 \%$ of cultural representation comprises aspects of culture from English speaking countries with only 5 out of 8 of cultural elements described.

Syahri and Susanti's (2016) study focuses on local and target culture percentages in English textbooks for senior high school in Indonesia. They analyse nine textbooks in which paragraphs and pictures are used as data units. Byram's (1989) checklist is used as the theoretical approach to quantitatively and qualitatively to analyse the data, followed by the categorisation of the 
cultural aspects under Cortazzi and Jin's (1999) types of culture: source culture, target culture, and international target culture. The findings show that only half of the selected-analysed textbooks present local cultures as opposed to target and international target culture. The study discusses types of culture but does not elaborate on how and which cultural aspects are represented in the textbooks. Further research dealing with more specific cultural aspects of culture and their representation is necessary.

The present study employs Byram's (1989) checklist, which provides eight cultural dimensions. Michael Byram is considered to be one of the most prominent researchers on intercultural learning and cultural content in the context of foreign language textbooks. He has proposed these criteria to comprehensively and critically investigate textbooks that encompass not only sociological factors but also social, historical, and geographical factors (Sorongan, Susanti, \& Syahri, 2014). There are eight cultural-dimension checklist items proposed by Byram's (1989). First dimensions are social identity and social group which include social class, ethnic minority and majority, regional identity, professional identity, and an individual's social identities. Second dimension is social interaction that encompasses a situation or manner used in a certain group of society; it includes verbal and non-verbal behaviour in social interaction, differing levels of formality, and characters (feelings, attitudes, values, and perceived problems). Third dimensions are belief and behaviour which concern about daily activities in society that involve religious and moral values. Fourth dimensions are social and political institution that deal with institutions in the country, for instance, a specific department for certain business affairs, and seeks to look at the meaning and values of the institution. Fifth dimension are socialisation and the life cycle 
REGISTER JOURNAL

Vol. 13, No. 1, (2020), pp.123-152

p-ISSN: 1979-8903 ; e-ISSN : 2503-040X

Website: http://journalregister.iainsalatiga.ac.id/index.php/register/

that include a smaller level of institutions, for instance, family, school, and the office, as well as ceremonies that mark passage through stages of social life. Sixth dimension is national history which encompasses historical and contemporary moments, which are pivotal for supporting teaching and learning in the classroom. Seventh dimension is national geography that refers to geographical features associated with a certain group of people and their environment. The last dimensions are stereotypes and national identity which reveals the landmarks of nations, including artefacts, popular places, or people.

\section{RESEARCH METHOD}

The present study focuses on the analysis of cultural dimension in the 2017 grade 10 English textbook in Indonesia. It is a qualitative study that investigates Buku Siswa Bahasa Inggris SMA Kelas 10, which was revised in 2017 in accordance with the 2013 curriculum. It consists of 15 chapters that present 17 reading passages, 11 dialogues, and 83 images. The analysis employs Byram's (1989) checklist which provides eight cultural dimensions.

The study is categorised as a content analysis in which the researcher establishes a set of categories and counts the data that belongs to the categories. Content analysis aims to identify meaning from a certain document or archive (Miles, Huberman, \& Saldana, 2013). A broad-based definition dealing with content analysis is present in Krippendorf's (2004) text: It defines content analysis as a technique that aims for replicable and valid inferences from texts as to the contexts of their use. In addition to giving this definition, he explains that content analysis is an analytical technique for measuring the frequency, order or intensity of occurrences of words, phrases, or sentences. The analysed 
text can take the written, spoken, or visual form, for instance books, pictures, films, and documents, in the context of communication, and the content can vary, including words, pictures, themes, ideas and any messages (Cohen, Manion, \& Morrison, 2000; Neuman, 1997)

A content analysis study involves three general steps for analysing data: data reduction, data presentation, and conclusion and verification (Miles and Huberman, 2013). This study employs a priori coding (Stemler, 2001) by establishing a coding checklist prior to the analysis based upon the theoretical frameworks applied and revising the categories accordingly. The step after coding is data display in the form of graphs, tables, or charts. It seeks to support the explanations of the findings quantitatively and is followed by communicative elaboration. The last step is a conclusion based on the findings. The main purpose of content analysis is transferability instead of generalizability: the findings may not be the same as those of other studies, but they are relevant in certain contexts (White \& Marsh, 2006). However, Weber (1990) notes that there is no single exact method of conducting content analysis. Hence, the researcher has constructed the guides to consistently select and analyse the data.

There are five guides in selecting and analysing the conversation. First, every conversation is explored in this study despite its length and section in which it occurs. Second, a conversation in the speaking or exercise section is still investigated if it presents a character or context that enables the researcher to interpret it accurately. Third, conversations revealed in the images or tied to illustrations are not analysed because they are investigated as part of the visual analysis. Fourth, the analysis of cultural dimension in conversations focuses on finding the contexts of conversation and arranging them into lists of cultural 
REGISTER JOURNAL

Vol. 13, No. 1, (2020), pp.123-152

p-ISSN: 1979-8903 ; e-ISSN : 2503-040X

Website: http://journalregister.iainsalatiga.ac.id/index.php/register/

dimensions and categories. Finally, it should be considered that one conversation may represent more than one cultural dimension or category.

In addition, the researcher also developed a guide used to select and analyse the reading texts. First, every reading text is analysed in this study despite its length. Second, one reading text may reveal more than one cultural dimension and category. The last one is about the method used for investigating where researcher generates a main idea or context for the text and labelling it with cultural dimensions and categories.

Illustration in the textbook is also part of unit analysis. Illustrations can take the form of photographs, drawings, and cartoons. The focus of investigation is the character portrayed in the illustration. "Character" means that the illustration which reveals a context that researchers can interpret. The researcher applies several guides to consistently select the unit of analysis and investigate the cultural dimensions. First, every illustration in the textbook is investigated. The illustration can be defined as a picture, a photograph, a drawing, or a cartoon that reveals a certain character or context. Second, if one chapter, even one page, reveals more than one illustration that presents the same or a different character or context, those illustrations are counted and investigated to determine the frequency of the illustration. Third, repeated illustrations are also counted because they show the frequency of cultural representation in the textbook. Fourth, one illustration may represent more than one character, and it is labelled according to those relevant cultural dimensions or categories. Fifth, a caption, instruction, or written text dealing with the illustration will be considered if necessary to accurately interpret the data. The 
last one is an illustration without a certain character, context, or scene will be labelled as an uncategorised cultural dimension. It may indicate an unnecessary illustration incorporated in the textbook or inconsistency between the illustration and caption.

\section{RESULTS \& DISCUSSION}

This part encompasses three main parts: the analysis of conversations, reading texts and visual elements. Byram's (1989) checklist is used to analyse the cultural dimensions incorporated in the textbook. The theoretical frameworks are applied to three units of analysis (conversations, reading texts, and visual elements) to gain a comprehensive overview dealing with cultural dimension in the textbook. The findings are presented through the discussion of the analysis to answer the research questions constructed at the beginning of the study. What are the cultural dimensions revealed in the grade 10 English textbook for senior high school in Indonesia? The analysis is presented according to the dimensions disseminated in each unit.

Table 1: Frequency and percentage of cultural dimensions

\begin{tabular}{lcc}
\hline \multicolumn{1}{c}{ Dimensions } & Frequency & Percentage \\
\hline A. Social identity and social group & 15 & $9.1 \%$ \\
B. Social interaction & 26 & $15.9 \%$ \\
C. Belief and behaviour & 13 & $7.9 \%$ \\
D. Social and political institutions & 3 & $1.8 \%$ \\
E. Socialisation and the life cycle & 26 & $15.9 \%$ \\
F. National history & 10 & $6.1 \%$ \\
G. National geography & 20 & $12.2 \%$ \\
H. Stereotype and national identity & 46 & $28.05 \%$ \\
I. Uncategorised & 5 & $3.05 \%$ \\
\hline
\end{tabular}




$\begin{array}{lll}\text { Total } & 164 & 100 \%\end{array}$

\section{Stereotype and national identity}

The most prominent cultural dimensions in the English textbook have to do with stereotype and national identity $(28.05 \%$ of the total dimensions portrayed in conversations, reading texts, and visual illustrations). Stereotypes and national identity are disseminated in various forms, including artefact, popular places, and popular people. The inclusion of national identity is pivotal for learners because the textbook is prescribed for senior high school, during which learners have high curiosity and are on a quest to determine their own characters. Hence, presenting popular people who have many achievements or have made many contributions, for example, may give senior high school learners good role models. This idea is aligned with the main aim of the 2013 curriculum: developing students with good character and behaviour. Presenting popular places such as tourist area is important as it grants learners sufficient information dealing with their environment. In relation to English language learning, students find it easier to learn a language through content which they are familiar with and interested in.

\section{Social Interaction}

Social interaction refers to the situation and manner used in a certain group of society. This encompasses verbal and non-verbal communication, characters such as feelings, attitudes, values, and perceived problems. For 
example, in conversation analysis, the researcher found that Alif's friends congratulate him and he thanks them. This indicates a friendly situation and common communication manners in Indonesia: saying, "Thank you," to those who congratulate us. Verbal communication can also be identified in the congratulatory content. Rudi comments on Ben's jacket, Ben comments on Rudi's outfit, and Andi is congratulated. The conversation seems proportional once every person gets his/her turn to speak; this is how people respect each other in social contexts.

Another form of social interaction dimension revealed in the conversation is that non-verbal communication like a handshake. It is very common in Indonesia to shake hand with each other to congratulate even in the time when we meet each other. Handshaking can be identified as a friendly warm greeting and it belongs to attitude.

The inclusion of social interaction in the textbook may aim to provide a clear picture of how people conduct verbal and non-verbal communication daily. As a result, learners may understand a language as a communication tool that should be understood linguistically and used in the proper context.

\section{Socialisation and the Life Cycle}

Socialisation and life cycle have the same occurrences with social interaction, 26\%. Byram (1989) defines socialisation and life cycle as a lower level of institutions that more specifically concerns schools, families, and officers as socialisation institutions. Three themes represent this dimension: "Congratulating other," "Long weekend activities," and "Biology 
project." The representations involve two forms of socialisation institutions: school and family.

School is described through several sub-dimensions, including teaching and learning activities and a formal school uniform. Teaching and learning activities are identified through an illustration of a teacher and student teaching and learning in the class. The setting of several conversations takes place at schools. It is also evident in the caption of every illustration. School uniforms in Indonesia comprise white shirts and grey pants/skirts. Most illustrations dealing with school that include students wearing school uniforms. Other forms of this dimension feature a graduation ceremony, student competition, extracurricular activities, the classroom setting, and a school announcement.

The inclusion of school and family in the socialisation and life cycle dimension is considered as a means of building learners' awareness of school activities and family orientation. The two lower levels of institutions, that is, the school and the family, are fundamental socialisation institutions for the introduction of culture or values because learners are familiar with the activities within those environments. In other words, it is easier for learners to learn a language through a culture in which they are familiar with.

\section{National Geography}

Another dimension that has high representation is national geography $(11.8 \%)$. It takes the form of the geographical features of certain places (a mountain, forest, waterfall, etc.). The presentation of the geographical dimension is crucial for providing learners with sufficient information. It can be used as a material for teaching 
descriptive or narrative text in the English-teaching and English-learning context. In addition, the representation of national geography in the textbook can be interpreted as the introduction of nature and the promotion of tourism sites. Hence, learners may be aware of the geographical features in their environments. Moreover, in the language-teaching and language-learning context, presenting geographical features could be included in the text recounting lesson: This involves describing a place or narrative text, which is easy for the learners to do because it is about their own environment. However, the representation of Niagara Falls may promote the United States' and Canada's cultural aspects. Therefore, learners become aware of cultural aspects of other countries.

\section{Social Identity and Social Group}

The social identity and social group dimension achieve a frequency of $8.9 \%$, and it is disseminated in the form of social status, social class, and professional identity. Social identity and social group refer to the identification of certain groups within the nation and include social status, social class, majority and minority ethnic groups, and professional identity (Byram, 2004). In the English textbook, social status describes the nobility and the ordinary class in Indonesia, while social class entails different situations among the rich and disadvantaged class and people living in the city and village. Social status differences exist in "Meeting idols," showing how celebrities and fans have different social statuses. Celebrities are assumed to be high-class people since their fans worship them, and their fans are assumed to have a lower-class status. The fans are very 
REGISTER JOURNAL

Vol. 13, No. 1, (2020), pp.123-152

p-ISSN: 1979-8903 ; e-ISSN : 2503-040X

Website: http://journalregister.iainsalatiga.ac.id/index.php/register/

excited about meeting their idols and describe it as an unforgettable experience. This shows celebrities' and fans' class differences in Indonesian society. This phenomenon is also evident in the text about Issumboshi, which draws a contrast between village and city conditions. People living in the village tend to be associated as poor and disadvantaged, while those who live in the city tend to be viewed as rich, educated, and have many advantages.

Different social statuses are also evident reading texts such as Habibie's story: His father is an agriculturalist, but his mother is a noble woman from Java. The same thing is also associated with Cut Nyak Dhien that is portrayed in the textbook, who is from an aristocratic family and marries a man from an aristocratic family as well. These descriptions reveal the differences in social class between aristocrats and ordinary people. The conditions are replicated in several places in Indonesia, where people are categorised under several social statuses.

The representation of professional identity, social class, and social status aims to provide learners with a comprehensive understanding regarding differences in social class and social status that exist in society. In language learning, this is important because different social classes or statuses might communicate in culturally different ways. In addition to this dimension, professional identity is described to inspire learners to be professionals and to offer them role models.

\section{Belief and Behaviour}

The belief and behaviour dimension constitutes $7.7 \%$ of all dimensions represented in all the units. It is presented in the form of religious identity, 
which includes religious behaviour, religious character, good behaviour, and holy places. Religious value is evident in several themes, for instance, "A letter from Saidah": The greetings are written in an Islamic way, "Assalamu alaikum," which means, "Peace be upon you." It is very common for Muslims to state that sentence when they meet, communicate, or interact. Another religious value is evident in the text about Cut Nyak Dhien: She is described as a female Muslim hero from Aceh.

Religious activity is only evident in the text about Issumboshi. It indicates that the queen is praying in the temple before doing other activities. The temple is the holy prayer building for Buddhists. Furthermore, moral values are disseminated through three themes: "Habibie" (though his father is an agriculturalist, he successfully pursues his degree in Germany and returns to Indonesia to contribute to its national development), "Malin Kundang" (a child should respect his/her mother, otherwise he/she will be unfortunate in life) and "Strong wind" (those who are patient and honest when confronting problems will achieve the best results).

Determining which religious values to present is a sensitive matter. The representation of belief and behaviour is fundamental since it serves to give students the perspective that different religions may be associated with different values or behaviours and that does not matter. Presenting various forms of belief and behaviour may give students wider perspectives of tolerance. However, it is still less represented in the textbook. 


\section{National History}

Another dimension in the textbook is that of national history. It represents only $5.9 \%$ in the form of stores about heroes and innovation. The textbook includes historical figures such as Bung Tomo and Cut Nyak Dhien as the symbol of struggle for Indonesians in Surabaya and Aceh respectively. Bung Tomo is the leader of Surabaya's people, who led the battle against the Dutch, while Cut Nyak Dhien is a female Indonesian hero who led the battle in Aceh. Another indicator of national history is the illustration of B. J. Habibie, a well-known, influential public figure in Indonesia. Another form of national history is the representation of the Taj Mahal, a famous monument and historical building in Indian national history.

Incorporating national history in an English textbook may enable learners to familiarise themselves with their own culture and other cultures, especially in the national history context. In the Indonesian context, one of the learning objectives for every subject as stated in the curriculum is to build learners' character. Presenting national heroes and the national history of Indonesia and its achievement of independence is considered to be government efforts to build learners' national character. In the English-learning context, national history can be presented to learners through the process of teaching students to recount the text. Students are bound to find it interesting because they are familiar with the figures in the stories. The inclusion of national heroes and innovation may build learners' awareness of the importance of taking lessons from them. The lessons deal with their motivation to make good contributions to their countries. Students are expected to take 
these lessons and hold onto them as basic principles in their lives, thus contributing positively to their countries.

\section{Social and Political Institution}

The dimension that considered least represented is that of social and political institutions: only $4.7 \%$. It is represented through government institutions that focus on technology affairs in reading texts. There is government institution representation in, which addresses a cancellation announcement. The text describes how government authorities engaged in a security ban of a concert in Singapore. Another representation of this dimension is about the Battle of Surabaya: The governor of Surabaya made an agreement with the Dutch at the time. These are described as a political institution.

One more representation of social and political institution occurs in the textbook is about B.J.Habibie. He is described as an influential figure in the technology department of the Ministry of Science and Technology in the Republic of Indonesia. This clearly shows how the social and political dimensions are incorporated in the textbook.

Learners are expected to know that the information deals with social and political institutions. However, the representations are considerably fewer. Apart from the eight cultural dimensions above, uncategorised dimensions also occur among the visual elements. They relate to unclear illustrations that do not present characters related to the described dimensions. 


\section{CONCLUSION}

Since 2013 curriculum was officially implemented, the English textbook has been revised for four times, and the present study investigates the newest version of the textbook. The focus of the study is the exploration of cultural aspects represented in the textbook. Data for analysis is selected from the textbook; it includes conversations, reading texts, and visual elements. Stereotype and national identity dominate the cultural dimensions in the English textbook. Indications of stereotypes and national identity are disseminated in various form, including artefacts, popular places, and popular people. Artefacts encompass popular buildings and historical buildings, while popular people take the form of national heroes, football players, and artists. The inclusion of national identity is pivotal for learners because the textbook is prescribed for senior high school learners, who are tremendously curious to determine their characters. Hence, presenting representations of popular people who have many achievements or have made many contributions, for example, may be useful for senior high school learners and may give them good role models. This idea is aligned with the main aim of the 2013 curriculum, which is to facilitate the development of students with good character, good behaviour, and strong nationality.

On the other hand, Byram (2004) promotes intercultural citizenship that includes linguistic competence and cultural competence to indicate that learners should learn not only the language but also the culture of the language. In addition, Hymes (1972) further explains that communicative competence can be understood as the ability to use language not only grammatically but also appropriately. Intercultural competence will help students develop 
multicultural awareness and a certain level of respect and tolerance for others (Cortazzi \& Jin, 1999; McKay, 2003). The researcher concludes that the present English textbook is on the way to perfection in terms of proportionally represented cultural dimensions. The textbook has widely incorporated local culture in form of the eight dimensions, however, presenting other cultures, target language culture and international culture, toward intercultural communicative competence.

\section{REFERENCES}

Adaskou, K., Britten, D., \& Fahsi, B. (1990). Design decisions on the cultural content of a secondary English course for Mororcco. ELT Journal, 44, 3 10. https://doi.org/10.1093/elt/44.1.3

Aliakbari, M., \& Jamalvandi, B. (2012). Realization of Culture in English Textbook in Chinese High School Level. Pan-Pacific Association of Applied Linguistics, 16(2), 89-100.

Alptekin, C. (1993). Target-Language Culture in EFL Materials. ELT Journal, 47(2), 136-143. https://doi.org/10.1093/elt/47.2.136

Alptekin, C. (2002). Towards Intercultural Communicative Competence in ELT. ELT Journal, 56, 57-64. https://doi.org/10.1093/elt/56.1.57

Apple, M. W., \& Beyer, L. E. (1983). Social Evaluation of Curriculum. Educational Evaluation and Policy Analysis, 5(4), 425-434.

Arsland, S. (2016). An Analysis of Two Turkish EFL Books in Terms of Cultural Aspects. Procedia-Social and Behavioural Sciences, 232, $217-$ 225 . 
Bahrami, N. (2015). Evaluating the Representation of Cultural Elements in an In-use EFL Textbook. Advances in Language and Literary Studies, 6, 128-236. https://doi.org/10.7575/aiac.v.6n.3p.128

Byram, M. (1989). Cultural Studies in Foreign Language Education. Clevedon: Multilingual Matters.

Byram, M. (2004). Teaching and Assessing Intercultural Communicative Competence. Clevedon: Multilingual Matters.

Chao, T. (2011). The Hidden Curriculum of Cultural Content in Internationally Published ELT Textbooks: A Closer Look at New American Inside Out. The Journal of ASIA TEFL, 8, 189-210.

Cho, Y., \& Park, Y. (2016). "Textbook as a Contradictory Melting-pot”: An Analysis of Multicultural Content in Korean Textbooks. Asia Pacific Journal of Education, 36, 111-130.

Cohen, L., Manion, \& Morrison, K. (2000). Research Methods in Education (5th ed.). London.

Cortazzi, M., \& Jin, L. (1999). Cultural Mirrors: Materials and Methods in ELT Classroom. In E.Heinkel (Eds.), Culture in Second Language Teaching. Cambridge: Cambridge University Press.

Crawford, J. (1990). How Authentic is the Language in Our Classrooms? Prospect, 6(1), 47-54.

Cummins, J. (1994). Knowledge, Power, and Identity in Teaching English as a Second Language. In Genesee (Ed.), Educating Second Language Children. Cambridge: CUP. 
Dweik, B. S., \& Al-Sayyed, S. W. (2015). Analysing the Cultural Content of Action PACK 12. International Journal of English Language and Linguistics Research, 3, 1-28.

Faris, I. N. I. (2014). Cultural Content Analysis of An English Textbook for Senior High School Grade Three, West Java. Journal of English and Education, 2, 14-25.

Fitriyah, L. (2015). An Analysis of Culture on the Reading Material Textbook in the Second Grade Junior High School. ELT Perspective, 3, 340-351.

Gray, J. (2000). The ELT Course book as Cultural Artefact: How Teachers Censor and Adapt. ELT Journal, 54(3), 274-283.

Hermawan, B., \& Noerkhasanah, L. (2012). Traces of Cultures in English Textbooks for Primary Education. Indonesian Journal of Applied Linguistics, 1, 49-60.

Hutchinson, T., \& Torres, E. (1994). The Textbook as Agent of Change. ELT Journal, 48(4), 315-327.

Hyde, M. (1994). The Teaching of English in Morocco: The Place of Culture. ELT Journal, 48(4), 295-305.

Hymes, D. (1972). On Communicative Competence. In: Pride JB, Holmes J (eds.) Sociolinguistics. Harmondsworth: Penguin.

Isik, A. (2008). Linguistic Imperialism and Foreign Language Teaching. The Journal of ASIA TEFL, 5(1), 123-144.

Jenkins, J. (2006). The Spread of English as an International Language: A Testing Time for Testers. ELT Journal, 60, 42-50. https://doi.org/10.1093/elt/cci080

Krippendorf, K. (2004). Content Analysis: An Introduction to Its Methodology (2nd ed.). CA: Sage. 
Lee, I. (2007). Preparing pre-service English teachers for reflective practice (Vol. 6). Oxford University Press.

Mahmood, M. A., Asghar, Z. M., \& Hussain, Z. (2012). Cultural representation in ESL textbooks in Pakistan: A case study of "Step Ahead 1." Journal of Education and Practice, 3(9), 35-42.

McKay, S. (2003). Teaching English as International Language. ELT Journal, 57(2), 139-148.

Miles, M. B., Huberman, A. M., \& Saldana, J. (2013). Qualitative Data Analysis: A Methods Sourcebook. Sage Publications, Incorporated.

Moran, P. (2001). Language and Culture. In Teaching culture: Perspectives in Practice. Boston, MA: Heinle and Heinle, 34-47.

Neuman, W. (1997). Social Research Methods: Qualitative and Quantitative Approaches (3rd ed.). MA: Allyn and Bacon.

Phillipson, R. (1992). Linguistics Imperialism. Oxford: Oxford University Press.

Piaget, J. (1928). Judgement and Reasoning in the Child. New Jersey: Littlefield.

Prastiwi, Y. (2013). Transmitting Local Culture Knowledge through English as Foreign Language (EFL) Learning as a Neabs of Fostering "Unity in Diversity." Academic Journal of Interdisciplinary Studies, 2, 507-513. https://doi.org/10.5901/ajis.2013.v2n3p507

Ramirez, G. A., \& Hall, K. J. (1990). Language and Culture in Secondary Level Spanish Textbooks. Modern Language Journal, 74, 48-65. 
Rashidi, N. (2010). The Representation of culture in Iran Language Institute Advanced Level Textbooks. Journal of Language Teaching \& Research, $1,624-631$.

Rashidi, N., \& Meihami, H. (2016). Hidden Curriculum: An Analysis of Cultural Content of the ELT Textbooks in Inner, Outer, and Expanding Circle Countries. Cogent Education, 3, 1-17.

Rodriguez, A. R., \& Espinar, A. M. (2015). General and Specific Culture Learning in EFL Textbooks Aimed at Adult Learners in Spain. Studia Anglica Posnaniensia, 50, 5-25. https://doi.org/10.1515/stap-2015-0014

Sorongan, D., Susanti, R., \& Syahri, I. (2014). An Analysis of Local and Target Culture Integration in English Textbooks. LINGUA, Jurnal Bahasa Dan Sastra, 15(1), 29-34.

Stemler, S. (2001). An overview of content analysis. Practical Assessment, Research and Evaluation. https://doi.org/10.1362/146934703771910080 Syahri, I., \& Susanti, R. (2016). An Analysis of Local and Target Culture Integration in the English Textbooks for Senior High School in Palembang. Journal of Education and Human Development, 5(2), 97-102.

Weber, R. (2011). Basic Content Analysis. In Basic Content Analysis. https://doi.org/10.4135/9781412983488

White, M. D., \& Marsh, E. E. (2006). Content Analysis: A Flexible Methodology. Library Trends, 55, 22-45. 